\section{ECONOMICS}

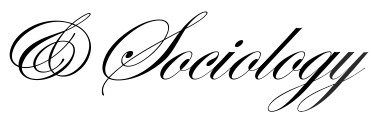

Nguyen Ngoc-Tan, FaME, Tomas Bata University in Zlin, Crech Republic based at Hanoi University, Vietnam. E-mail: ngoctanhanu@gmail.com

Aleš Gregar, FaME, Tomas Bata University in Zlin, Crech Republic

E-mail:gregar@utb.cr.

Received: November, 2017

1st Revision: February, 2018

Accepted: June, 2018

DOI: $10.14254 / 2071-$

789X.2018/11-3/18

JEL Classification: D83, O39, I23
Ngoc-Tan, N., \& Gregar, A. (2018). Impacts of Knowledge Management on Innovation in Higher Education Institutions: An Empirical Evidence from Vietnam. Economics and Sociology, 11(3), 301-320. doi:10.14254/2071-

789X.2018/11-3/18

\title{
IMPACTS OF KNOWLEDGE MANAGEMENT ON INNOVATION IN HIGHER EDUCATION INSTITUTIONS: AN EMPIRICAL EVIDENCE FROM VIETNAM
}

\begin{abstract}
Knowledge management (KM) and innovation (INNO) are often defined as the key drivers for improvement of organizational performance. The purpose of this paper is to explore the impacts of $\mathrm{KM}$ on INNO in an academic environment. The results of this study are based on survey data collected during 2017 in 30 public universities equally located in 3 regions of Vietnam. Structural Equation Modelling (SEM) is used to test the hypothesized relationships between KM and INNO. The authors of this study have found that KM comprehensively impacts technical INNO in academic settings and that not all components of $\mathrm{KM}$ are directly associated with administrative INNO. Besides enriching the literatures on this rapport, this study is also of value in managerial perspective as it helps increase higher education institutions' (HEIs) knowledge on how to boost their organisational innovativeness, and then enhance performance by engaging in KM activities. A list of measurement scales serving as a checklist for leadership of any HEI desire to practice KM and then boost organizational innovation is provided by this study.
\end{abstract}

Keywords: knowledge management, innovation, higher education institutions, public universities, Vietnam

\section{Introduction}

Over the past decades, knowledge management (KM) has proved itself not a trendy movement in research but a new discipline drawing a growing body of researches worldwide. It has been deemed a new and influential approach in the science of management. It is KM, a new source of sustainable competitive advantage that makes organisations all over the globe redefine their business strategies. There is a mainstay of researches showing that KM is an antecedents and foundation for organisational innovation (Chen et al., 2010; Lin et al., 2012; Lee et al., 2013). Extant literature states that KM processes including creation, acquisition, dissemination, utilisation (Chen et al., 2010; Lin et al., 2012; Lee et al, 2013), KM practices including supervisory work, leadership, policies, communication, knowledge protection, strategic KM, knowledge-based training, recruiting, performance appraisal, compensation, learning mechanism, IT practices (Gloet \& Terziovski, 2004; Denti \& Hemlin, 2012; Roffe, 
1999; Martins \& Terblanche, 2003; Henri TapioInkinen, Aino Kianto, Mika Vanhala, 2015) or knowledge-based assets like human, structural and relational capital (Wang \& Chen, 2013; Castro et al., 2013; Menor et al., 2007; Aramburu \& Saenz, 2011) exert impacts on innovation (INNO). There are, however, only a few empirical studies focusing on the relationship between $\mathrm{KM}$ and INNO being conducted in academic settings, more specifically in higher education institutions.

To fill this gap in the existing literature, this study desires to provide empirical evidence on how KM impacts INNO in public universities of Vietnam. The purpose of this paper is to help increase HEIs' knowledge on how to boost their organisational innovativeness by engaging in KM activities. Besides, the paper also contributes to KM and INNO management literature by exploring KM's impacts on INNO in HEIs of Vietnam. The paper first theoretically introduces the concepts of KM and INNO, then empirically examines the relationship of three KM components including knowledge acquisition, knowledge dissemination, and knowledge utilization with 2 components of INNO including administrative and technical INNO. SPSS 22.0 and AMOS 23.0 have been deployed to process data collected by means of structured survey from 30 public universities equally located in three regions of Vietnam. The results of data analysis are shown and discussed before the paper comes to conclusion. Recommendations for future research are also presented. This paper is part of a bigger study on the relationship between KM and organisational performance with the mediating role of INNO.

\section{Literature review}

\section{KM defined}

According to Gloet and Terziovski (2004), there is no shortage of KM definition. Depending on the approaches and author's perspectives, the definition of KM is devised accordingly.

Looking at KM from process perspective, Nonaka and Takeuchi (1995) studied how knowledge is produced, used, and diffused within organizations and how such knowledge contributes to the diffusion of INNO. KM is divided into four part viz., knowledge creation, knowledge retrieval, knowledge sharing and knowledge application. This process was reconfirmed by Wilson and Cattell (2005).

There are numerous researches referring to $\mathrm{KM}$ as a generic processes like knowledge acquisition, sharing, and creation (e.g. Chen et al., 2010; Lee et al., 2013). Alrawi (2008) believed KM involves three perspectives emerged, information based one, a technology based one and a culture based one. Therefore, Ho (2009) supported the viewpoint by saying KM is result-oriented, process oriented, technology oriented, culture oriented and HR-oriented and supported by four key enablers viz., leadership, culture, technology, and measurement. Plessis (2007) and Gloet and Terziovski (2004) offered more comprehensive ones. Plessis (2007) defines $\mathrm{KM}$ as a planned structure approach to managing creation, sharing, harvesting and leveraging of knowledge as an organizational asset to enhance a company's ability, speed and effectiveness in delivering products or services for the benefit of clients in line with its business strategy (p 22). Meanwhile, Gloet and Terziovski (2004) describe KM as the formalization of and access to experience, knowledge, and expertise that create new capabilities, enable superior performance, encourage INNO, and enhance customer value.

Despites a large number of researchers have investigated KM activities and process; there's still no unanimous KM. In the context of organizational learning, Argote (1999) distinguishes between three processes: creating knowledge, retaining knowledge, and transferring knowledge. Chen and Chen (2005) propose a four-stage model of the KM process 
that includes knowledge creation, which, in addition to adding new knowledge, includes correction of existing knowledge, knowledge conversion, and knowledge circulation and completion. Miller (1999) suggests that KM refers to the acquisition of knowledge (capturing); that is, creation, collection, storage, distribution, and application of knowledge According to Demarest (1997), KM consists of five processes: construction, embodiment, dissemination, use, and management while Armistead (1999) divides the process of KM into three sub processes: knowledge creation, knowledge transfer, and knowledge embedding. According to Darroch (2003), the KM process consists of three parts: knowledge acquisition, knowledge dissemination, and knowledge utilization. Meanwhile, Kaba and Ramaiah (2017) believe that $\mathrm{KM}$ is the appropriate application and implementation of knowledge development process. By embarking on KM journey, organization has an ability to provide all it needs for creating, preserving, disseminating, and using knowledge as needed.

\section{KM in education}

According to Dev Raj Adhikari (2010), KM in educational institutions can be defined as the organized and systematic process of generating and disseminating information, and selecting, distilling, and deploying explicit and tacit knowledge to create unique value that can be used to strengthen teaching-learning environment. Mikulecky and Mikulecka (1999) believed that, by its nature, university environment is suitable for the application of KM principles and methods. This can be explained by the following reasons: (i) universities usually possess modern information infrastructure, (ii) knowledge sharing with others is natural for lecturers, and (iii) the desire of students is to acquire knowledge from accessible sources as fast as possible. Nilsook and Sriwongkol (2009) said KM in higher education has three objectives: first, developing tasks for better quality and effectiveness; second, developing human resources in all operating levels; and third, developing knowledge bases of organizations or sectors towards the enhanced knowledge investment or wisdom investment of the organizations.

A wide approach to KM can lead to exponential improvements in sharing knowledge; both explicit and tacit, and the subsequent surge benefits for an educational institution. Every part of colleges and universities' mission could be supported if KM practices are applied - from education to public service to research. Maponya (2004) stated that if applied effectively, it can result in better decision-making capabilities, shorten "product" development cycle time, improved academic and administrative services, and reduced costs. KM application may provide collaborative solutions and higher learning, technological issues, learning, knowledge, competition, teacher training, resolution of student problems, assistance to business and industry, adoption of projects at more extended levels, movement of resources for enhancing development, and achievement of sustainability. Furthermore, they showed that increasing the use of KM leads to enhancements in INNO and development.

Mathew (2010) argued that KM provides some of the solutions to the problems that are relevant for sustainable higher education teaching learning processes. Using KM techniques and technologies in higher education is as vital as it is in the corporate sector. Kidwell et al. (2000) argue that KM is vital to higher education institution, bringing crucial benefits to educational institution processes such as research, curriculum development, student and alumni services, administrative services and strategic planning. Dev Raj Adhikari (2010) stressed that in today's world, trying to manage the educational institutions without KM initiatives can bring about downfall.

This study adopts Gloet and Terziovski and Pleisiss's approach toward KM since they clearly point out the role of KM towards INNO and firm performance and the author will also choose Darroch's definition of KM to guide this study. 


\section{INNO defined}

In an increasingly volatile and competitive business environment, it is imperative for organisations, with their all resources, put in place systems and processes to ensure the desired outcomes in the interest of all stakeholders. To that end, solutions have been sought for and one of them is INNO. The concept has enjoyed immense popularity in both business research and practice.

According to Damanpour et al (2009), literature views INNO as a valuable instrument enabling the firm to obtain greater capability to respond and adapt to the changes in its environment (and thus to discover new opportunities on the market and exploit them to a greater extent than do its rivals). Zahra and Covin, 1995; Camiso'n and Lo'pez, 2010; Alipour and Karimi, 2011; Rubera and Kirca (2012) support the viewpoint by reconfirming that in recent years, a growing body of research has examined the way in which INNO contributes to better entrepreneurial performance. James A. Odumeru (2013) is also of the same opinion when saying that INNO is a key determinant of organisational performance. Robbins and Coulter (2006) defined INNO as the process of adopting creative ideas and turning them into useful products or work methods. This is unlike invention which these authors describe as the process of developing new ideas.

INNO is defined as "the creation of new knowledge and ideas to facilitate new business outcomes, aimed at improving internal business processes and structures and to create market driven products and services" (Plessis, 2007, p. 21). Damanpour, 1991; Camiso'n and Fore's, 2010; Molina and Marti'nez (2010) believed INNO has been understood alternately as the transformation of knowledge that the firm possesses into products and processes, and as significant changes in existing processes and products to introduce them in the market. Further, many articles that have studied the relationship between INNO and knowledge demonstrate that knowledge is a precursor of INNO (Cohen and Levinthal, 1990; Tsai, 2001; Zahra and George, 2002; Camiso'n and Fore's, 2010). Urbancová, H. (2013) states that innovations are a key source of a competitive advantage that determines the economic success of each organization. Ungerman, O., Dedkova, J., Gurinova, K. (2018) empirically concludes that innovation as a factor in competitiveness.

In a nutshell, INNO is a new strategy that is widely accepted by most organisations in contemporary economies. It's deemed a tool to enhance competitive advantage and improve organisational performance. INNO is even regarded as a key determinant of organisational performance. However, the type and degree of INNO varies across industries. Therefore, every organisation seeking competitive advantage and improved performance must consider the inclusion of appropriate type of INNO for achieving desired outcomes.

According to Seng et al (2011), evidence in literature indicated the existence of at least eight types of INNO: Process INNO, Product INNO, Incremental INNO, Radical INNO, Administrative INNO, Technology INNO, Market INNO and Value INNO. Among numerous typologies of INNO advanced in the relevant literature, three have gained the most attention. Each features a pair of types of INNO: administrative and technical, product and process, and radical and incremental.

Evan (1966) said the distinction between administrative and technical INNO is important because it relates to a more general distinction between social structure and technology. In addition, Daft (1978) stressed that administrative and technical INNO imply potentially different decision-making processes, and together they represent changes introduced in a wide range of activities in an organization. While, technical INNO pertain to products, services, and production process technology; they are related to basic work activities and can concern either product or process (Damanpour \& Evan, 1984; Knight, 1967), administrative INNO involve organizational structure and administrative processes; they are indirectly related 
to the basic work activities of an organization and are more directly related to its management (Damanpour \& Evan, 1984; Kimberly \& Evanisko, 1981; Knight, 1967).

\section{Innovation in Education}

Educational institution, serving the needs of the society, is indispensible for the survival and development of the society. It must continuously evolve to meet the challenges of the increasingly volatile world. The evolution requires engagement of all stakeholders of that complex organisation (the learners, parents, teacher, educational administrators, researchers, and policy makers) for an innovative teaching and learning environment in order to produce high quality students who are ready to life and work. Educational INNO can be progress seen in any or all aspects of the educational system including theory and practice, curriculum, teaching and learning, policy, technology, institutions and administration, institutional culture, and teacher training.

According to Peter Serdyukov (2017), educational INNO has become more urgent than ever. Socio-economic well-being of a country depends greatly on the quality of its citizen's education. INNO in education are of particular importance because education plays a crucial role in creating a sustainable future.

\section{Administrative innovation}

According to Liao et al., (2008), administrative INNO is defined as new procedures, policies and organizational forms, and innovative operation with respect to planning, organization, personnel, leadership, management, and service. Damanpour (1991) was of the same opinion when stating that administrative INNO involves organizational structure and administrative processes related to work activities of the organization and its management. Subramanian and Nilakanta (1996) shared the viewpoint when emphasizing that administrative INNO is the main component of organizational INNO and it refers to a new management system, administrative process, and staff development program. Meanwhile, Yamin et al., (1997) believed administrative INNO potentially promotes work redesign and work systems, skills enhancement, management systems, and changes in incentives. It is considered a valuable tool which organisations have implemented so as to survive in the competitive, uncertain and volatile context.

\section{Technical innovation}

Subramanian and Nilakanta (1996) argued that this component of organizational INNO is more about adopting new ideas relating to new products or services or introduction of new elements in an organization's production process or service operations. Liao et al., (2008) also believed technical INNO is the INNO with respect to products, manufacturing and facilities. According to Armbruster et al., (2008), technical INNO affects the routines, processes and operations of an organization concerning process, product or service. By doing so it exerts its positive impacts on the speed and flexibility of production and the quality of production. Thus, technical INNO definitely promotes the organization to encourage competitive advantage, achieve organisational excellence, gain organizational advantage, and enhance organisational performance and business sustainability. It becomes a significant tool in helping organisations achieve competitive advantage in rough market.

This study, therefore, chooses technical and administrative INNO to guide the research. 


\section{Relationship between KM and INNO}

According to Kumar et al., (2000), knowledge is generally believed to be one of the keys to fostering INNO since it promotes activities that create or improve the firm's processes. Rhodes et al., (2008) supports the viewpoint by stating that knowledge is a momentous resource for strategic organisation in enhancing INNO and organisational performance improvement.

Many studies have analyzed the positive relationship between knowledge and INNO (Molina \& Martı'nez, 2010; Zheng, 2010; Camelo et al., 2011). Those studies have also indicated that KM could play a major role in higher organisational performance (Bierly \& Daly, 2007; Choi et al., 2008; Chong et al., 2009; Schulz \& Jobe, 2001; Turner \& Bettis, 2002). KM and INNO enjoy correlated and reciprocal effect. Majchrzak et al. (2004) demonstrated that the $\mathrm{KM}$ implementation is a strategy to improve INNO. It is regarded as the best way to enhance INNO (Majchrzaket al., 2004; Rhodes et al., 2008). In addition, Yahya and Goh (2002) described KM as a process to enhance knowledge application to achieve INNO or improving business performance meanwhile; the INNO process involves the acquisition, dissemination, and use of new and existing knowledge (Damanpour, 1991; Moorman and Miner, 1998). An organization's innovativeness is closely tied to its ability to utilize its knowledge resources (Subramaniam \& Youndt, 2005). Jantunen (2005) stresses that INNO is a knowledge-based process to create new ideas, markets, products and services toward achieving competitive advantage by satisfying maximum number of customers, which in turns establishes an organization as a brand.

The positive relationship between KM and INNO has been proved and gain popularity in literature. According to Chen and Huang (2009), KM capacity in terms of acquisition, sharing, and application provides a positive contribution to the firm's INNO performance. Effective KM facilitates knowledge communication and exchange required in the INNO process and further enhances INNO performance through the development of new insights and capabilities (Madhavanand Grover, 1998; Nonaka \& Takeuchi, 1995; Von Krogh, 1998). Therefore, knowledge management capacity plays a pivotal role in supporting and fostering INNO. The role of KM in the INNO capacity enhancement of organization is well-established and predominant in the literature (Darroch \& McNaughton, 2002; Fosfuri \& Tribo, 2006; Gray, 2006; Chen \& Huang, 2009).

Review of literature provides substantial information on the positive relationship between KM and INNO; however, few of them can empirically show evidence between those two crucial factors in a specific context. Author of this paper, therefore, hypothesize that KM and INNO are also significantly associated in the settings of public universities in Vietnam.

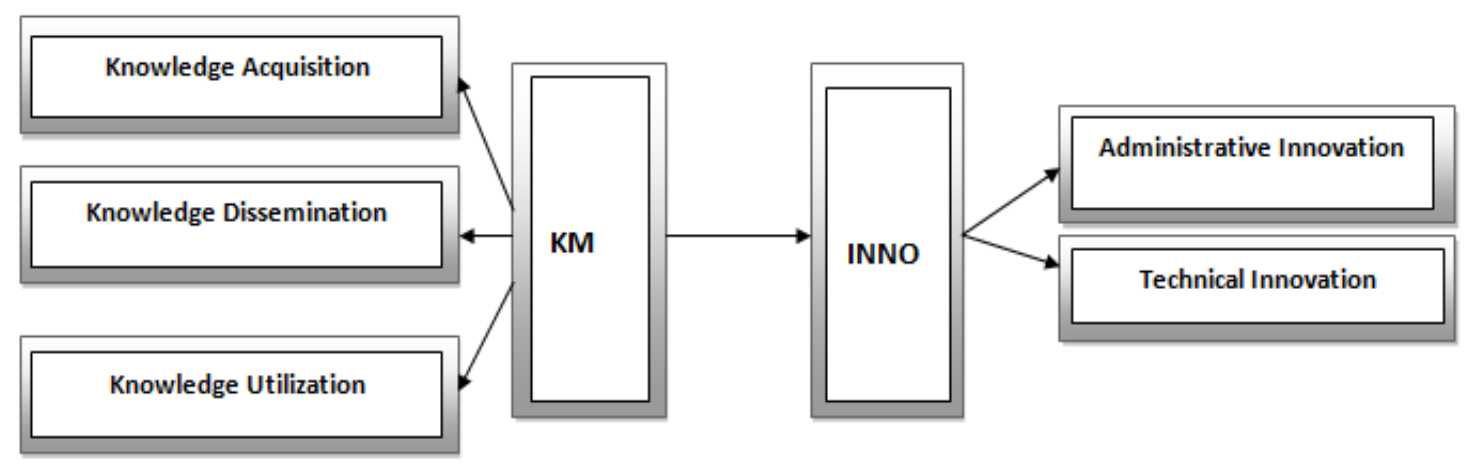

Fig 1. Conceptual framework

Source: author 
Accordingly, the main hypothesis can be broken into the following sub-hypothesis based on the conceptual framework Vietnam.

$\mathrm{KM}$ and INNO are significantly associated in the settings of public universities in

H1. Knowledge acquisition is significantly associated with administrative INNO in the settings of public universities in Vietnam.

H2. Knowledge dissemination is significantly associated with administrative INNO in the settings of public universities in Vietnam.

H3. Knowledge utilisation is significantly associated with administrative INNO in the settings of public universities in Vietnam.

H4. Knowledge acquisition is significantly associated with technical INNO in the settings of public universities in Vietnam.

H5. Knowledge dissemination is significantly associated with technical INNO in the settings of public universities in Vietnam.

H6. Knowledge utilization is significantly associated with technical INNO in the settings of public universities in Vietnam.

\section{Methodology}

\section{Sample and data collection}

\section{Pilot survey}

After the questionnaire of 42 items measuring 3 components of $\mathrm{KM}$ and 2 components of INNO is carefully translated into Vietnamese, pilot survey was performed before officially delivering to the targeted respondents. A pilot survey of 15 samples for each version (English and Vietnamese) of the questionnaire was conducted. Comments and feedbacks from the pilot survey helped improve the readability, clarity and comprehensiveness of the questionnaire. Besides, bias is also avoided in the final version. Respondents of this research are public university administrators of Vietnam ranging from middle- level managers to top ones. They are leadership of faculties, functional departments and university.

Sample size

According to the note 1279/BGDDT-KHTC dated March 17 ${ }^{\text {th }}, 2014$ issued by Ministry of Education and Training of Vietnam (MOET), there are 149 public universities nationwide. The research chose only $20 \%$ of them in each region of Vietnam to ensure the representativeness which is equivalent to 30 universities. Around 20 questionnaires were distributed to each selected university. This means some 600 samples will be collected for the study as suggested by Bollen 5:1 (1989).

Questionnaires were sent directly in hard copies via post and soft copies via email to head of Research Management Department of each university who later helped disseminate and collect them at their universities.

Sample characteristics

Out of 600 samples delivered, 531 were returned make the response rate up to $88.5 \%$. $24.7 \%$ universities involved in the research follow orientation development of research; other $37.0 \%$ and $38.3 \%$ follow applied and hybrid orientation respectively. The most represented (94.6\%) are multi-disciplined ones; only $4.6 \%$ are single-disciplined. The majority of universities $(44.8 \%)$ take part in this project are of medium size (size is measured by number of students, small $<10.00 ; 10.000<$ medium $>20.000$; big $>20.000$ ); other $27.9 \%$ and $27.3 \%$ are 
small and big size respectively. 64\% sampled universities are established during 1955-1990 and the rest are founded after 1990.

\section{Measures}

\section{Independent variables}

$\mathrm{KM}$ in this research is primarily measured by scales adopted from Lawson (2003). There are 3 components of KM (see Appendix) including knowledge acquisition (with 11 scale items of which 6 are adopted from Lawson (2003); 5 are self-developed), knowledge dissemination (with 12 scale items of which 7 are adopted from Lawson (2003), 5 are self-developed), knowledge utilisation (with 5 scale items are totally adopted from Lawson (2003)). All of the measures were based on five-point Likert scales (1-strongly disagree, 5-strongly agree).

\section{Dependent Variables}

Innovation in this study is consists of 2 components (see Appendix) including administrative and technical innovation. Administrative innovation is measured by 7 scale items inspired by Liao et al., (2008), Damanpour (1991), Brennan et al., (2014) and OECD. (2013). Meanwhile, Technical innovation is also measured by 7 scale items inspired by Subramanian and Nilakanta (1996), Armbruster et al., (2008) and Brennan et al., (2014). All of the measures were based on five-point Likert scales (1-strongly disagree, 5-strongly agree).

\section{Statistical methods}

The data collected was processed through several stages.

First, reliability and internal consistency analysis were performed to test whether the measures were applicable for the construct measurement. Internal consistency is evaluated by construct reliability and convergent validity. Values of Cronbach's alpha and statistical significance of factor loadings were assessed.

Second, correlation analysis was conducted in order to identify any interconnectedness between independent variables and dependent variables. The strength of correlation and statistical significance will be tested.

Third, discriminant validity indicating if constructs actually differ from each other was checked by comparing the average variance extracted (AVE) by individual constructs and the shared variance between a given construct and other constructs in the model.

Fourth, confirmatory factor analysis (CFA) was performed to validate and find the reliability of any measurement in most social science studies (Harrington, 2009). The objective of CFA is to test whether the data fits a hypothesized measurement model. The author of this study used AMOS version 23.0 to perform CFA.

Finally, structural equation modelling (SEM) for statistical testing of the hypothesized relationships was used. AMOS 23.0 was deployed to facilitate this analysis.

\section{Results}

\section{Reliability}

Cronbach's $\alpha$ was conducted to examine the internal consistency of multi-item constructs. All constructs prove their reliability. Knowledge acquisition (KA), knowledge dissemination (KD) and knowledge utilisation (KU) have values of 0.890, 0.926 and 0.892 respectively. Meanwhile, administrative innovation (ADINNO) and technical innovation (TECHINNO) achieve values of 0.771 and 0.857 respectively. However, the following items including KA5, KA6, KA8, KA10, KA11; KD3; ADINNO6, ADINNO7; TECHINNO5, TECHINNO7 did not meet the requirement by analysing the inter-item correlation matrix. They are, therefore, left out of the model for conducting the reliability test again. By now, the KA, 
$\mathrm{KD}, \mathrm{KU}, \mathrm{ADINNO}$, TECHINNO achieve the values of $0.869,0.925,0.892,0.884$, and 0.846 respectively.

All constructs have the values that are above the generally accepted threshold value of 0.7 (Bagozzi \& Yi, 1991) and are adequate for the next step of factor analysis.

\section{Validity}

Factor analysis with promax rotation was adopted to check the unidimensionality among items since each variable was measured by multi-item constructs. The EFA begins with the determination of the Kaiser Meyer-Olkin Measure of Sampling Adequacy value that knowledge management (KM) and innovation (INNO) equals 0.914 and 0.852 respectively which is higher than the suggested value of 0.70 . The Bartlett Test of Sphericity was significant $(p=0.00)$. Principal axis factoring analysis using promax rotation was conducted to test the emergence of 3 factors in KM (KA, KD, KU) and 2 factors in INNO (ADINNO, TECHINNO). The number of factors actually extracted was determined by the number of items with eigenvalue more than 1. For missing values, cases were excluded list wise. For discriminant validity, factor loadings less than 0.5 were suppressed. Analysis was performed on 22 items of KM and 10 items of INNO in this study. All factors loaded satisfactorily (see table VI). This result tells us that all the remaining items related to their specific constructs, verifying the posited relationships among the indicators and constructs.

To ensure constructs differ from each other, discriminant validity test was conducted. Only when the AVE of the construct is greater than the variance shared between that construct and the other constructs in the model (i.e. the squared correlation between two constructs) is the test valid (Fornell \& Lacker, 1981). All the constructs in this study met this condition; especially, the diagonal elements (AVEs) were greater than off-diagonal elements in the corresponding rows and columns (see Table 1).

Table 1. Discriminant Validity

\section{AVE matrix}

\begin{tabular}{lccccc}
\hline & KD & KA & KU & ADINNO & TECHINNO \\
\hline KD & 0.5299 & & & & \\
\hline KA & 0.0141 & 0.5399 & & & \\
\hline KU & 0.0199 & 0.0008 & 0.6257 & & \\
\hline ADINNO & 0.0004 & 0.0001 & 0.0400 & 0.5967 & \\
\hline TECHINNO & 0.0153 & 0.0089 & 0.0171 & 0.0110 & 0.5229 \\
\hline
\end{tabular}

Source: statistical analysis generated by researcher

Note: AVE associated with the construct is presented diagonally; the squared correlations between constructs are presented in the lower left triangle.

\section{Correlation analysis}

The mean values, standard deviations and correlation matrix are demonstrated in Table 2. Significant correlations are found between independent and dependent variables. More specifically, the correlation analysis statically shows that KD is correlated with KA, KU and TECHINNO; KA is correlated with TECHINNO; KU is correlated with ADINNO and TECHINNO; and there is connectedness between ADINNO and TECHINNO. 
Table 2. Correlation Matrix for the research model

\begin{tabular}{|c|c|c|c|c|c|c|c|c|}
\hline & & Mean & $\begin{array}{c}\text { Std. } \\
\text { Deviation }\end{array}$ & KD & KA & KU & ADINNO & TECHINNO \\
\hline \multirow[t]{2}{*}{$\mathrm{KD}$} & $\begin{array}{c}\text { Pearson } \\
\text { Correlation }\end{array}$ & \multirow{2}{*}{4.108} & \multirow{2}{*}{0.964} & 1 & & & & \\
\hline & $\begin{array}{c}\text { Sig. (2- } \\
\text { tailed) }\end{array}$ & & & & & & & \\
\hline \multirow[t]{2}{*}{ KA } & $\begin{array}{c}\text { Pearson } \\
\text { Correlation }\end{array}$ & \multirow{2}{*}{4.081} & \multirow{2}{*}{0.968} & $.119^{* *}$ & & & & \\
\hline & $\begin{array}{l}\text { Sig. (2- } \\
\text { tailed) }\end{array}$ & & & .006 & & & & \\
\hline \multirow[t]{2}{*}{ KU } & $\begin{array}{c}\text { Pearson } \\
\text { Correlation } \\
\end{array}$ & \multirow{2}{*}{3.339} & \multirow{2}{*}{0.950} & $.141^{* *}$ &.- & & & \\
\hline & $\begin{array}{c}\text { Sig. (2- } \\
\text { tailed) }\end{array}$ & & & .001 & .522 & & & \\
\hline \multirow[t]{2}{*}{ ADINNO } & $\begin{array}{c}\text { Pearson } \\
\text { Correlation }\end{array}$ & \multirow{2}{*}{3.270} & \multirow{2}{*}{0.948} & -.020 & $\begin{array}{c}- \\
.007 \\
\end{array}$ & $.200^{* *}$ & & \\
\hline & $\begin{array}{c}\text { Sig. (2- } \\
\text { tailed) }\end{array}$ & & & .638 & .871 & .000 & & \\
\hline \multirow[t]{2}{*}{ TECHINNO } & $\begin{array}{c}\text { Pearson } \\
\text { Correlation }\end{array}$ & \multirow{2}{*}{3.930} & \multirow{2}{*}{0.921} & $.124^{* *}$ & $.095^{*}$ & $.131^{* *}$ & $.105^{*}$ & \\
\hline & $\begin{array}{c}\text { Sig. (2- } \\
\text { tailed) }\end{array}$ & & & .004 & .029 & .003 & .015 & 1 \\
\hline
\end{tabular}

**. Correlation is significant at the 0.01 level (2-tailed).

*. Correlation is significant at the 0.05 level (2-tailed).

Source: statistical analysis generated by researcher

Confirmatory factor analysis

In order to achieve model fit, fit statistics tests like the relative $\chi^{2}$ (the $\chi^{2}$ /degree of freedom), Tucker Lewis index (TLI), comparative fit index (CFI), goodness of fit index (GFI), and root mean square of error approximation (RMSEA) were selected. The relative $\chi^{2}\left(\chi^{2} / \mathrm{df}\right)$ must be between 2 and 5 in order to achieve acceptable model fit. The TLI, CFI, GFI and AGFI values should be in the range of 0 to 1 with values close to 1 indicating a good fit while the RMSEA value should fall below 0.08 to indicate an acceptable fit to the data (Schumacker \& Lomax, 2004). Results of CFA for KM and INNO are as below:

Table 3. Results of CFA for KM and INNO

\begin{tabular}{lccccccc}
\hline Factors & $\begin{array}{c}\text { Chi square/ } \\
\text { df }\end{array}$ & P value & GFI & TLI & CFI & RMSEA & Note \\
\hline CFA KM & 1.527 & 0 & 0.950 & 0.980 & 0.983 & 0.032 & fit \\
\hline CFA INNO & 1.872 & 0,02 & 0.976 & 0.984 & 0.988 & 0.041 & fit \\
\hline
\end{tabular}

Source: statistical analysis generated by researcher

Testing the research models

The results show some are as hypothesized, some are not. On the one hand, the path estimates from KD to TECHINNO ( $\mathrm{B}=0,089, \mathrm{p}<0.05)$, KA to TECHINNO $(\mathrm{B}=0,123, \mathrm{p}<0.05)$, 
KU to TECHINNO $(\mathrm{B}=0,091, \mathrm{p}<0.05)$, and $\mathrm{KU}$ to ADINNO $(\mathrm{B}=0,248, \mathrm{p}<0.05)$ are in line with hypotheses; hence, hypotheses $\mathrm{H} 3, \mathrm{H} 4, \mathrm{H} 5, \mathrm{H} 6$ are supported.

On the other hand, path estimates from KA to ADINNO ( $B=0,001, p>0.05)$ is statistically insignificant; $\mathrm{KD}$ to ADINNO $(\mathrm{B}=-0,058, \mathrm{p}>0.05)$ is contrary to hypothesis $\mathrm{H} 2$. Thus, $\mathrm{H} 1$ and $\mathrm{H} 2$ are not supported and rejected.

Table 4. Testing the research models

\begin{tabular}{lllccc}
\hline Independent Variables & & Dependent variables & Estimate & P & \\
\hline KnowledgeDissemination & $==>$ & AdministrativeInnovation & -.058 & .313 & $\begin{array}{c}\text { Not supported (P } \\
>5 \%)\end{array}$ \\
\hline KnowledgeDissemination & $==>$ & TechnicalInnovation & .089 & .022 & $\begin{array}{c}\text { Supported }(\mathrm{P}< \\
5 \%)\end{array}$ \\
\hline KnowledgeAcquisition & $==>$ & AdministrativeInnovation & .001 & .993 & $\begin{array}{c}\text { Not supported ( P } \\
>5 \%)\end{array}$ \\
\hline KnowledgeAcquisition & $==>$ & TechnicalInnovation & .123 & .040 & $\begin{array}{c}\text { Supported ( P } \\
5 \%)\end{array}$ \\
\hline KnowledgeUtilisation & $==>$ AdministrativeInnovation & .248 & $* * *$ & $\begin{array}{c}\text { Supported ( P } \\
5 \%)\end{array}$ \\
\hline KnowledgeUtilisation & $==>$ & TechnicalInnovation & .091 & .006 & $\begin{array}{c}\text { Supported (P< } \\
5 \%)\end{array}$ \\
\hline
\end{tabular}

Note: $* * *$ Significant at $<0.10$ and $<0.05$ respectively

Table 5. Summary of findings

\begin{tabular}{lc}
\hline Hypotheses & \\
\hline H1. Knowledge acquisition is significantly associated with administrative & $\begin{array}{c}\text { Not } \\
\text { INNO in the settings of public universities in Vietnam. }\end{array}$ \\
\hline $\begin{array}{l}\text { H2. Knowledge dissemination is significantly associated with administrative } \\
\text { INNO in the settings of public universities in Vietnam. }\end{array}$ & $\begin{array}{c}\text { Not } \\
\text { supported }\end{array}$ \\
\hline H3. Knowledge utilisation is significantly associated with administrative INNO & Supported \\
in the settings of public universities in Vietnam. & \\
\hline $\begin{array}{l}\text { H4. Knowledge acquisition is significantly associated with technical INNO in } \\
\text { the settings of public universities in Vietnam. }\end{array}$ & Supported \\
\hline $\begin{array}{l}\text { H5. Knowledge dissemination is significantly associated with technical INNO } \\
\text { in the settings of public universities in Vietnam. }\end{array}$ & Supported \\
\hline $\begin{array}{l}\text { H6. Knowledge utilization is significantly associated with technical INNO in } \\
\text { the settings of public universities in Vietnam. }\end{array}$ & Supported \\
\hline
\end{tabular}

\section{Discussions}

All in all, the results of this study enrich the understanding of how knowledge should be managed for the benefits of an academic institution.

Firstly, the empirical result demonstrates that KM (KA, KD, and KU) comprehensively and positively impacts technical innovation in a public university of Vietnam. This help reaffirms what Jantunen (2005) said that innovation is a knowledge-based process to create new ideas, markets, products and services and accordingly this will bring about competitive advantages for an organization. KM practices of creating, sharing, storing and using serve as enablers for innovation performance in a public university. By deploying KM initiatives, an 
academic institution can utilize it knowledge resource to develop new products or services, improve its existing products or services by offering new courses and disciplines which are in social demand. This is also in line with what Madhavan and Grover (1998), Nonaka and Takeuchi (1995), Von Krogh (1998) and Subramaniam and Youndt (2005) stated in their research that KM further enhances INNO performance by developing new insights and capabilities.

Besides, results of the study also reveal that by embarking on the KM journey, an academic institution is more aware of the importance and facilitates knowledge exchange, communication and interaction among its stakeholders (students, staff and industry) for the better organizational performance and competitiveness. By consulting students and staff as well inviting industry engagement, an academic institution can improve its curriculums and assessment process periodically toward producing market-based products and services by which helps enhance the learning-teaching quality meeting up with quality assurance criteria (MBNQA, 1999). This is also emphasized by Damanpour (1991), Camiso'n and Fore's (2010), Molina and Martı'nez (2010) when stressing that INNO helps transform knowledge that the firm possesses into products and processes; INNO performs significant changes in existing processes and products to introduce them to the market.

Secondly, statistical evidence of the research results indicates that KM partially influences administrative INNO of an academic institution. Of the 3 components in the KM process including knowledge acquisition, knowledge dissemination and knowledge utilization, only the path estimate from knowledge utilization $(B=0,248, p<0.05)$ is statistically significant. This can be explained by looking at the KM cycle itself and nature of administrative innovation. Administrative innovation is more about organisational structure, administrative process, procedures, infrastructure, staff development program, work design system and policies. Those are main components for organizational innovation (Subramanian and Nilakanta, 1996). This type of organizational innovation directly benefits from how knowledge is utilized in an organization. Meanwhile, KM cycle normally starts from generating, creating (acquisition), sharing (dissemination) and applying (utilization); all those stages of the cycle are interconnected. The evidence of KM's impact on administrative innovation (ADINNO) seems more visible at the stage of knowledge application. The statistically insignificant relationships between KA and ADINNO, KD and ADINNO do not mean that KA and KD do not play any role in ADINNO. In reality, they are prerequisites and indirectly contribute to organizational innovativeness and organizational performance. This reflects what Yahya and Goh (2002) reiterated in their study looking at one aspect of $\mathrm{KM}$ cycle that $\mathrm{KM}$ is a process that enhances knowledge application to achieve innovation or improving business performance.

\section{Conclusion}

\section{Implications for theory}

This study provides empirical evidence about the positive association between KM and INNO in academic setting. By this, it helps empirically affirm multiple conjectures that are made about the correlated relationship between KM and INNO especially in the academic context and, at the same time, enriches the literatures on this rapport. The study also reveals that technical innovation is comprehensively influenced by KM process; meanwhile, of the 3 components of KM process, only KU can exert its direct impacts on administrative innovation. In addition, the study also adds to literatures on innovation management in academic context by demonstrating the impacts of $\mathrm{KM}$ as a managerial tool for increasing organizational innovation; vice versa, it enriches literatures on $\mathrm{KM}$ and its best practices in academia. 


\section{Implication for managers}

Overall, this study contributes to better understanding of the potentially most effective $\mathrm{KM}$ practices and initiatives that are likely to improve innovation then, performance of an academic institution; hence, it may serve as guidelines for the administrators in those institutions. Findings of this study are of value for leadership of academic institutions since they are directly related to their daily routines. The findings may spark administrator's interest and actions once they wish to board on the journey of knowledge management.

Results of this study suggest administrators of academic institutions raise their awareness about the importance of KM and INNO and take appropriate actions and route map to practice KM initiatives; devise KM-based policies in the ways that help boost innovation and finally the performance of the organization.

A list of measurement scales serving as a checklist for leadership of any academic institution desire to practice $\mathrm{KM}$ and then boost organizational innovation is provided by this study.

For knowledge acquisition, administrator in academic institution should pay adequate attention to nurturing a culture of being open to new-to-the world things, sharing and exchange. Infrastructure must be supportive for smooth communication including technological infrastructure. Budget must be spent on learning materials, software, intellectual products and even human resource of high quality. Though, cross-functional training scale statistically failed to meet up reliability requirement in this research, it still need to consider in practice.

For knowledge dissemination, different platforms, forums and resource centers must be available for knowledge sharing. Organisational knowledge must be well organized and easy to get access to. Priorities must be given to developing different form of publications, organizational database and repositories. In addition, system of seminar, conference and symposium must be periodically held together with running apprenticeship or novice teacher mentoring program. On of very important factor in knowledge dissemination is that stakeholders of the institution must be provided with formal, informal and virtual space to interact with each other for knowledge exchange. Although patent and copyright of organizational knowledge in not now well-perceived in Vietnam, it needs sufficient care in practicing KM.

For knowledge utilization, this is the stage that make KM most visible. Administrators must know how to deploy organizational knowledge in resolving problems and achieving competitiveness. For sustainable use and nurture a KM culture in the institution, critical evaluation of organizational knowledge must be conducted to generate new pattern and knowledge for future use. Besides, methods for filtering and cross-listing outdated knowledge, integrating different types and sources of knowledge are also essential.

By exercising KM practices, the institutional innovativeness will be advanced and, likewise, its performance.

\section{Limitations and recommendations for future research}

This study bears some limitations due to the chosen research design and context, which leave room for further research directions. Firstly, this study chooses to examine KM and INNO in a very specific context or an education in a developing country - Vietnam. The result may, therefore, not be generalized and representative. Secondly, although it is not a big problem in this study, respondents of this research are all managerial staff and they may talk good about their organization. A qualitative survey is recommended in combination with quantitative one to avoid bias for future researches. Thirdly, comparative studies of KM and INNO between industries other than education or education of different countries may be interesting theme for 
future researchers. Fourthly, one-time study conducted in a cross-sectional research setting has some limitations. Time-series data of a longitudinal would allow researchers to have better understanding of a causal relationship between KM and INNO. This is highly recommended directions for future studies.

\section{References}

Alipour, F., \& Karimi, R. (2011). Mediation role of innovation and knowledge transfer in the relationship between learning organization and organizational performance. International Journal of Business and Social Science, 2(19), 144-147.

Alrawi, K.W. (2008). Knowledge management and organizations perception in the United Arab Emirates. International Journal of Commerce and Management, 18(4), 382-394.

Argote, L. (1999). Organizational Learning: Creating, Retaining and Transferring Knowledge, Norwell, MA: Kluwer.

Aramburu, N. \& Sáenz, J. (2011). Structural capital, innovation capability, and size effect: An empirical study, Journal of Management and Organization, 17(3), 307-325.

Armbruster, Heidi, Bikfalvi, Andrea, Kinkel, Steffen, \& Lay, Gunter. (2008). Organizational Innovation: The Challenge of Measuring Non-Technical Innovation in Large-Scale Surveys. Technovation, 28, 644-657.

Bagozzi, R. P., \& Yi, Y. (1991). Multitrait-multimethod matrices in consumer research. Journal of consumer research, 17(4), 426-439.

Bierly III, P. E., \& Daly, P. S. (2007). Alternative knowledge strategies, competitive environment, and organizational performance in small manufacturing firms. Entrepreneurship theory and practice, 31(4), 493-516.

Bollen, K. A. (1989). Structural equations with latent variables. New York, NY: John Wiley, 1989.

Brennan, J., Broek, S., Durazzi, N., Kamphuis, B., Ranga, M., \& Ryan, S. (2014). Study on innovation in higher education. Publications Office of the European Union, Luxembourg. ISBN 9789279350818

Camelo-Ordaz, C., Garcia-Cruz, J., Sousa-Ginel, E., \& Valle-Cabrera, R. (2011). The influence of human resource management on knowledge sharing and innovation in Spain: the mediating role of affective commitment. The International Journal of Human Resource Management, 22(07), 1442-1463.

Camisón, C., \& Forés, B. (2010). Knowledge absorptive capacity: New insights for its conceptualization and measurement. Journal of Business Research, 63(7), 707-715.

Camisón, C., \& Villar López, A. (2010). An examination of the relationship between manufacturing flexibility and firm performance: The mediating role of innovation. International Journal of Operations \& Production Management, 30(8), 853878.

Castro, G. M. D., Delgado-Verde, M., Amores-Salvadó, J., \& Navas-López, J. E. (2013). Linking human, technological, and relational assets to technological innovation: exploring a new approach. Knowledge Management Research \& Practice, 11(2), 123 132.

Chen, C. J., Huang, J. W., \& Hsiao, Y. C. (2010). Knowledge management and innovativeness: The role of organizational climate and structure. International Journal of Manpower, 31(8), 848-870.

Chen, C. J., Huang, J. W., \& Hsiao, Y. C. (2010). Knowledge management and innovativeness: The role of organizational climate and structure. International Journal of Manpower, 31(8), 848-870. 
Chen, Chung-Jen, \& Huang, Jing-Wen (2009). Strategic human resource practices and innovation performance-The mediating role of knowledge management capacity. Journal of Business Research, 62, 104-114.

Chen, M. \& Chen, A. (2005). Integrating option model and knowledge management performance measures: an empirical study. Journal of Information Science, 31 (5), 381393.

Choi, B., Poon, S. K., \& Davis, J. G. (2008). Effects of knowledge management strategy on organizational performance: A complementarity theory-based approach. Omega, 36(2), 235-251.

Chin Wei, C., Siong Choy, C., \& Kuan Yew, W. (2009). Is the Malaysian telecommunication industry ready for knowledge management implementation?. Journal of knowledge management, 13(1), 69-87.

Cohen, W. M. (1983). Absorptive capacity: a new perspective on learning and innovation. Administrative Science Quarterly, 35, 147-160.

Daft, R. L., \& Becker, S. W. 1978. The innovative organization. New York: Elsevier.

Damanpour, F. (1991). Organizational innovation: A meta-analysis of effects of determinants and moderators. Academy of management journal, 34(3), 555-590.

Damanpour, F., \& Evan, W. M. (1984). Organizational innovation and performance: the problem of" organizational lag". Administrative science quarterly, 29, 392-409.

Damanpour, F., Walker, R. M., \& Avellaneda, C. N. (2009). Combinative effects of innovation types and organizational performance: A longitudinal study of service organizations. Journal of management studies, 46(4), 650-675.

Damanpour, F. (1991). Organizational innovation: A meta-analysis of effects of determinants and moderators. Academy of management journal, 34(3), 555-590.

Darroch, J. (2003). Developing a measure of knowledge management behaviors and practices. Journal of Knowledge Management, 7 (5), 41-54.

Darroch, J., \& McNaughton, R. (2002). Examining the link between knowledge management practices and types of innovation. Journal of Intellectual capital, 3(3), 210-222.

Demarest, M. (1997). Understanding knowledge management. Long range planning, 30(3), 374-384.

Denti, L., \& Hemlin, S. (2012). Leadership and innovation in organizations: A systematic review of factors that mediate or moderate the relationship. International Journal of Innovation Management, 16(03), 1240007.

Raj Adhikari, D. (2010). Knowledge management in academic institutions. International Journal of Educational Management, 24(2), 94-104. doi: 10.1108/09513541011020918

Du Plessis, M. (2007). The role of knowledge management in innovation. Journal of Knowledge Management, 11(4), 20-29. http://doi.org/10.1108/13673270710762684

Evan, W. M. (1966). Organizational lag. Human Organizations, 25(Spring), 51-53.

Fornell, C., \& Larcker, D. F. (1981). Evaluating structural equation models with unobservable variables and measurement error. Journal of marketing research, 18(1), 39-50.

Fosfuri, A., \& Tribó, J. A. (2008). Exploring the antecedents of potential absorptive capacity and its impact on innovation performance. Omega, 36(2), 173-187.

Gloet, M., \& Terziovski, M. (2004). Exploring the relationship between knowledge management practices and innovation performance. Journal of manufacturing technology management, 15(5), 402-409.

Gray, C. (2006). Absorptive capacity, knowledge management and innovation in entrepreneurial small firms. International Journal of Entrepreneurial Behavior \& Research, 12(6), 345-360.

Harrington, D. (2009). Confirmatory Factor Analysis, Oxford University Press, New York, NY. 
Inkinen, H. T., Kianto, A., \& Vanhala, M. (2015). Knowledge management practices and innovation performance in Finland. Baltic Journal of Management, 10(4), 432-455.

Ho, C. T. (2009). The relationship between knowledge management enablers and performance. Industrial Management \& Data Systems, 109(1), 98-117.

Jantunen, A. (2005). Knowledge-processing capabilities and innovative performance: An empirical study. European Journal of Innovation Management, 8(3), 336-349.

Kaba, A., \& Ramaiah, C. K. (2017). Demographic differences in using knowledge creation tools among faculty members. Journal of Knowledge Management, 21(4), 857-871. https://doi.org/10.1108/JKM-09-2016-0379

Kidwell, J. J., Vander Linde, K., \& Johnson, S. L. (2000). Applying corporate knowledge management practices in higher education. Educause quarterly, 23(4), 28-33.

Kimberly, J. R., \& Evanisko, M. (1981). Organizational innovation: The influence of individual,organizational, and contextual factors on hospital adoption of technological and administrativeinnovations. Academy of Management Journal, 24, 689 - 713.

Knight, K. E. (1967). A descriptive model of the intra-firm innovation process. Journal of Business, 40, 478-496.

Kumar, N., Scheer, L., \& Kotler, P. (2000). From market driven to market driving. European management journal, 18(2), 129-142.

Lawson, S. (2003). Examining the relationship between organization culture and KM. $\mathrm{PhD}$ thesis, Nova Southeastern University.

Lee, V. H., Leong, L. Y., Hew, T. S., \& Ooi, K. B. (2013). Knowledge management: a key determinant in advancing technological innovation?. Journal of Knowledge Management, 17(6), 848-872.

Lee, V. H., Leong, L. Y., Hew, T. S., \& Ooi, K. B. (2013). Knowledge management: a key determinant in advancing technological innovation?. Journal of Knowledge Management, 17(6), 848-872.

Liao, S. H., Fei, W. C., \& Liu, C. T. (2008). Relationships between knowledge inertia, organizational learning and organization innovation. Technovation, 28(4), 183-195.

Lin, R. J., Che, R. H., \& Ting, C. Y. (2012). Turning knowledge management into innovation in the high-tech industry. Industrial Management \& Data Systems, 112(1), 42-63.

Madhavan, R., \& Grover, R. (1998). From embedded knowledge to embodied knowledge: new product development as knowledge management. The Journal of marketing, 62(4), 1-12.

Majchrzak, A., Cooper, L. P., \& Neece, O. E. (2004). Knowledge reuse for innovation. Management science, 50(2), 174-188.

Maponya, P. M. (2005). Knowledge management practices in academic libraries: a case study of the University of Natal, Pietermaritzburg Libraries (Doctoral dissertation, Loughborough University).

Martins, E. C., \& Terblanche, F. (2003). Building organisational culture that stimulates creativity and innovation. European journal of innovation management, 6(1), 64-74.

Mathew, V. (2010, October). Knowledge management in higher education: Implementation agenda in distance learning. In Distance Learning and Education (ICDLE), 2010 4th International Conference on (pp. 155-158). IEEE.

Menor, L. J., Kristal, M. M., \& Rosenzweig, E. D. (2007). Examining the influence of operational intellectual capital on capabilities and performance. Manufacturing \& Service Operations Management, 9(4), 559-578.

Mikulecký, P., \& Mikulecka, J. (1999, November). Active tools for better knowledge dissemination. In ASIS 1999 Annual Meeting(pp. 420-427). Washington DC.

Miller, W. (1999). Building the ultimate resource. Management review, 1(1), 42-45.

Molina-Morales, F. X., \& Martínez-Fernández, M. T. (2010). Social networks: effects of social capital on firm innovation. Journal of Small Business Management, 48(2), 258-279. 
Molina-Morales, F. X., \& Martínez-Fernández, M. T. (2010). Social networks: effects of social capital on firm innovation. Journal of Small Business Management, 48(2), 258-279.

Moorman, C., \& Miner, A. S. (1998). Organizational improvisation and organizational memory. Academy of management review, 23(4), 698-723.

Nilsook, P., \& Sriwongkol, T. (2009, December). The Development of Multi-weblog with Knowledge Management for Thailand's Higher Education. In Information and Multimedia Technology, 2009. ICIMT'09. International Conference on (pp. 315-318). IEEE.

Nonaka, I., \& Takeuchi, H. (1995). The Knowledge-creating company - How Japanese companies create the dynamics of innovation, New York: Oxford University Press.

Odumeru, J. A. (2013). Innovation and Organisational Performance. Kuwait Chapter of the Arabian Journal of Business and Management Review, 2(12), 18.

OECD. (2013). Innovative Learning Environments. OECD Publishing. Retrieved from http://www.oecd-ilibrary.org/education/innovative-learningenvironments_9789264203488-en

Serdyukov, P. (2017). Innovation in education: what works, what doesn't, and what to do about it?. Journal of Research in Innovative Teaching \& Learning, 10(1), 4-33. doi: 10.1108/ JRIT-10-2016-0007

Plessis, M. (2007). The role of knowledge management in innovation. Journal of Knowledge Management, 11(4), 20-29.

Rhodes, J., Hung, R., Lok, P., Ya-Hui Lien, B., \& Wu, C. M. (2008). Factors influencing organizational knowledge transfer: implication for corporate performance. Journal of knowledge management, 12(3), 84-100.

Robbins, S.P. \& Coulter, M. (2006). Management (9th edition). New York, Prentice Hall.

Roffe, I. (1999). Innovation and creativity in organisations: a review of the implications for training and development. Journal of European industrial training, 23(4/5), 224-241.

Rubera, G., \& Kirca, A. H. (2012). Firm innovativeness and its performance outcomes: A metaanalytic review and theoretical integration. Journal of Marketing, 76(3), 130-147.

Schulz, M., \& Jobe, L. A. (2001). Codification and tacitness as knowledge management strategies: an empirical exploration. The Journal of High Technology Management Research, 12(1), 139-165.

Schumacker, R.E., \& Lomax, R.G. (1994). A Beginner's Guide to Structural Equation Modeling, Lawrence Erlbaum Associates, NJ.

Seng, L. K., Yusof, N. A., \& Abidin, N. Z. (2011). Types of Innovation Implemented by Housing Developer in Developing Countries. International Journal of Academic Research, 3(3). $614-618$.

Subramaniam, M., \& Youndt, M. A. (2005). The influence of intellectual capital on the types of innovative capabilities. Academy of Management journal, 48(3), 450-463.

Subramanian, A., \& Nilakanta, S. (1996). Organizational innovativeness: Exploring the relationship between organizational determinants of innovation, types of innovations, and measures of organizational performance. Omega, 24(6), 631-647.

Tsai, W. (2001). Knowledge transfer in intra organizational networks: effects of network position and absorptive capacity on business unit innovation and performance. Academy of Management Journal, 44(5), 996-1004.

Turner, S. F., Bettis, R. A., \& Burton, R. M. (2002). Exploring depth versus breadth in knowledge management strategies. Computational \& Mathematical Organization Theory, 8(1), 49-73.

Ungerman, O., Dedkova, J., \& Gurinova, K. (2018). The Impact of Marketing Innovation on the Competitiveness of the Enterprises in the Context of Industry 4.0. Journal of Competitiveness, 10(2), 132-148. https://doi.org/10.7441/joc.2018.02.09 
United Nations Economic and Social Commission for Western Asia (2005). National profile for the information society in Iraq, available at: www.escwa.un.org/wsis/reports/docs/ Iraq_2005 E.pdf (accessed 5 February 2016).

Urbancová, H. (2013). Competitive Advantage Achievement through Innovation and $\begin{array}{llll}\text { Knowledge. Journal of } & \text { Competitiveness, }\end{array}$ https://doi.org/10.7441/joc.2013.01.06

Von Krogh, G. (1998). Care in knowledge creation. California management review, 40(3), 133153.

Wang, D., \& Chen, S. (2013). Does intellectual capital matter? High-performance work systems and bilateral innovative capabilities. International Journal of Manpower, 34(8), 861-879.

Wilson, J.P., \& Cattel, A. (2005). Knowledge Management in Human Resource Development. Edited by Jhon. P.Wilson (2nd ed.) Kogan Page 2005.

Yahya, S., \& Goh, W.K. (2002). Managing human resources toward achieving knowledge management. Journal of Knowledge Management, 6(5), 457-468.

Yamin, S., Mavondo, F., Gunasekaran, A., \& Sarros, J. C. (1997). A study of competitive strategy, organisational innovation and organisational performance among Australian manufacturing companies. International Journal of Production Economics, 52(1-2), 161172.

Zahra, S. A., \& Covin, J. G. (1995). Contextual influences on the corporate entrepreneurshipperformance relationship: A longitudinal analysis. Journal of business venturing, 10(1), 43-58.

Zahra, S. A., \& George, G. (2002). Absorptive capacity: A review, reconceptualization, and extension. Academy of management review, 27(2), 185-203.

Zheng, W. (2010). A social capital perspective of innovation from individuals to nations: where is empirical literature directing us?. International Journal of Management Reviews, 12(2), 151-183.

- First author of this paper contributes $80 \%$ of intellectual share.

- The authors would like to thank the Internal Grant Agency of FaME for providing financial support to carry out this research. Funding was extended through: TBU No. IGA/FaME/2017/013 - The relationship between knowledge management and organisational performance with mediating role of innovation.

- Corresponding author can be reached at: ngoctanhanu@gmail.com 


\section{Appendix}

Table VI. Measurement items

\begin{tabular}{|c|c|c|c|c|}
\hline Concept & Item & $\begin{array}{l}\text { Factor } \\
\text { loading }\end{array}$ & AVE & CR \\
\hline \multirow{7}{*}{$\begin{array}{l}\text { Knowledge } \\
\text { Acquisition } \\
\text { (KA) }\end{array}$} & \multicolumn{4}{|c|}{$\begin{array}{l}\text { Please indicate the extent to which you disagree or agree with the following statements. } \\
\qquad(1=\text { Strongly disagree, } 5=\text { Strongly agree })\end{array}$} \\
\hline & $\begin{array}{l}\text { KA1. My institution encourages and has processes for the } \\
\text { exchange of ideas and knowledge between individuals and } \\
\text { groups (faculties and administrative staff). }\end{array}$ & .664 & \multirow{6}{*}{0.54} & \multirow{6}{*}{.869} \\
\hline & $\begin{array}{l}\text { KA2. My institution has a mechanism for creating and } \\
\text { acquiring knowledge from different sources such as } \\
\text { customers, employees, business partners and competitors. }\end{array}$ & .782 & & \\
\hline & $\begin{array}{l}\text { KA3. My institution responds to our ideas and documents } \\
\text { them for further development. }\end{array}$ & .648 & & \\
\hline & $\begin{array}{l}\text { KA4. My institution sets up regulations to encourage staff to } \\
\text { further study after a certain period of time working for the } \\
\text { institution. }\end{array}$ & .636 & & \\
\hline & $\begin{array}{l}\text { KA7. My institution recruits and hires quality professional or } \\
\text { teaching staff to increase grey matter in the organization. }\end{array}$ & .952 & & \\
\hline & $\begin{array}{l}\text { KA9. My institution annually spends certain amount of } \\
\text { budget to purchase learning and research materials. }\end{array}$ & .680 & & \\
\hline \multirow{12}{*}{$\begin{array}{l}\text { Knowledge } \\
\text { Dissemination } \\
\text { (KD) }\end{array}$} & \multicolumn{4}{|c|}{$\begin{array}{l}\text { Please indicate the extent to which you disagree or agree with the following statements. } \\
\qquad(1=\text { Strongly disagree, } 5=\text { Strongly agree })\end{array}$} \\
\hline & $\begin{array}{l}\text { KD1. My institution has libraries, resource centres and other } \\
\text { forums to display and disseminate knowledge. }\end{array}$ & .815 & \multirow{11}{*}{0.53} & \multirow{11}{*}{.925} \\
\hline & $\begin{array}{l}\text { KD2. My institution has knowledge in the form that is readily } \\
\text { accessible to us when needed. }\end{array}$ & .761 & & \\
\hline & $\begin{array}{l}\text { KD4. My institution has different publications to display the } \\
\text { captured knowledge. }\end{array}$ & .727 & & \\
\hline & $\begin{array}{l}\text { KD5. My institution has regular symposiums, lectures, } \\
\text { conferences and training sessions to share knowledge. }\end{array}$ & .787 & & \\
\hline & $\begin{array}{l}\text { KD6. My institution utilizes various written devices such as } \\
\text { newsletters, manuals to store the knowledge what they } \\
\text { capture. }\end{array}$ & .784 & & \\
\hline & $\begin{array}{l}\text { KD7. My institution utilizes databases, repositories and info } \\
\text { technology applications to store knowledge for easy access by } \\
\text { staff. }\end{array}$ & .678 & & \\
\hline & $\begin{array}{l}\text { KD8. My institution runs apprenticeship, mentor or coaching } \\
\text { program for the development of young staff. }\end{array}$ & .646 & & \\
\hline & $\begin{array}{l}\text { KD9. My institution provides space and occasion for } \\
\text { employees to talk and to listen to one another and interact } \\
\text { informally. }\end{array}$ & .673 & & \\
\hline & $\begin{array}{l}\text { KD10. My institution often forms up team with members } \\
\text { from different departments to involve in a special project. }\end{array}$ & .676 & & \\
\hline & $\begin{array}{l}\text { KD11. My institution has virtual space (i.e. website, forum, } \\
\text { intranet, internal e- mail system) for us to exchange ideas } \\
\text { among one another. }\end{array}$ & .749 & & \\
\hline & $\begin{array}{l}\text { KD12. My institution sends out timely reports with } \\
\text { appropriate information to us and other relevant institutions. }\end{array}$ & .703 & & \\
\hline \multirow{3}{*}{$\begin{array}{l}\text { Knowledge } \\
\text { Utilisation } \\
\text { (KU) }\end{array}$} & \multicolumn{4}{|c|}{$\begin{array}{l}\text { Please indicate the extent to which you disagree or agree with the following statements. } \backslash \\
(1=\text { Strongly disagree, } 5 \text { = Strongly agree })\end{array}$} \\
\hline & $\begin{array}{l}\text { KU1. My institution has methods to analyse and critically } \\
\text { evaluate knowledge to generate new patterns and knowledge } \\
\text { for future use. }\end{array}$ & .806 & \multirow[t]{2}{*}{0.626} & \multirow[t]{2}{*}{.892} \\
\hline & $\begin{array}{l}\text { KU2. My institution applies knowledge to critical competitive } \\
\text { needs. }\end{array}$ & .808 & & \\
\hline
\end{tabular}




\begin{tabular}{|c|c|c|c|c|}
\hline & $\begin{array}{l}\text { KU3. My institution has mechanism to protect knowledge } \\
\text { from inappropriate or illegal use inside and outside of the } \\
\text { institution. }\end{array}$ & .749 & & \\
\hline & $\begin{array}{l}\text { KU4. My institution has different methods to further develop } \\
\text { the knowledge and apply them to new situations. }\end{array}$ & .864 & & \\
\hline & $\begin{array}{l}\text { KU5. My institution has mechanism for filtering, cross-listing } \\
\text { and integrating different sources and type of knowledge. }\end{array}$ & .724 & & \\
\hline \multirow{6}{*}{$\begin{array}{l}\text { Administrative } \\
\text { Innovation } \\
\text { (ADINNO) }\end{array}$} & \multicolumn{4}{|c|}{$\begin{array}{l}\text { Please indicate the extent to which you disagree or agree with the following statements. } \\
\qquad(1=\text { Strongly disagree, } 5=\text { Strongly agree })\end{array}$} \\
\hline & $\begin{array}{l}\text { ADINNO 1. My institution deploys advanced management } \\
\text { methods (Eg. ISO). }\end{array}$ & .826 & \multirow{5}{*}{0.597} & \multirow{5}{*}{.884} \\
\hline & $\begin{array}{l}\text { ADINNO 2. My institution nurtures a culture towards INNO } \\
\text { (that enhances creativity, creates awareness of the benefits } \\
\text { resulting from the implementation of the INNO, stimulates } \\
\text { openness to INNO and minimizes resistance to change). }\end{array}$ & .777 & & \\
\hline & $\begin{array}{l}\text { ADINNO 3. Organizational structure of my institution is of } \\
\text { high flexibility and less administrative procedures. }\end{array}$ & .691 & & \\
\hline & $\begin{array}{l}\text { ADINNO 4. IT infrastructure facilitates the internal } \\
\text { communication of the institution. }\end{array}$ & .877 & & \\
\hline & $\begin{array}{l}\text { ADINNO 5. IT infrastructure facilitates governance of the } \\
\text { institution. }\end{array}$ & .717 & & \\
\hline \multirow{6}{*}{$\begin{array}{l}\text { Technical } \\
\text { Innovation } \\
\text { (TECHINNO) }\end{array}$} & \multicolumn{4}{|c|}{$\begin{array}{l}\text { Please indicate the extent to which you disagree or agree with the following statements. } \\
\qquad(1=\text { Strongly disagree, } 5=\text { Strongly agree })\end{array}$} \\
\hline & $\begin{array}{l}\text { TECHINNO 1. My institution constantly offers new courses, } \\
\text { disciplines and new modes of learning that are in demand to } \\
\text { compare with other institutions in the field. }\end{array}$ & .745 & \multirow{5}{*}{0.523} & \multirow{5}{*}{.846} \\
\hline & $\begin{array}{l}\text { TECHINNO 2. My institution frequently keeps improving } \\
\text { our existing products/services, processes by multiplied lesson } \\
\text { learnt and senior's experience, as a result, we are more } \\
\text { innovative compared with what we were. }\end{array}$ & .762 & & \\
\hline & $\begin{array}{l}\text { TECHINNO 3. Curricula are revised periodically at my } \\
\text { institution. }\end{array}$ & .708 & & \\
\hline & $\begin{array}{l}\text { TECHINNO } 4 \text {. Learners of my institution can contribute to } \\
\text { curricula construction and assessment process. }\end{array}$ & .675 & & \\
\hline & $\begin{array}{l}\text { TECHINNO 6. My institution has mechanism to collect and } \\
\text { analyse feedback information (from learners, organizations, } \\
\text { employers etc.) on performance and impact, and inform all } \\
\text { stakeholders. }\end{array}$ & .730 & & \\
\hline
\end{tabular}

Source: survey data 